\title{
Practical Modelling in Treehouse Development
}

\author{
Matijs Babris, Uǵis Bratuškins, Riga Technical University, Riga, Latvia
}

\begin{abstract}
Up-to-date nature tourism trends witness a growth of customer-oriented unique experiences. The present paper explores the potential of treehouses in nature tourism development in Latvia by providing unique and authentic experiences. Using the method of practical modelling several distinct treehouse construction methods are compared considering regional differences and different use cases. To achieve the set goal, three separate practical modelling workshops in different municipalities in Latvia were organised during the summer holidays of 2016-2018. History and construction types of treehouses were analysed as well as 30 experts from the local municipalities, treehouse companies, workshop participants, clients and customers were interviewed. The presented study is based on the 4-year experience of participation in several European treehouse workshops and organisation of the local treehouse activities and events in Latvia as well as learnings from managing an outdoor recreation company "Movement Spontaneous" and co-founding the Latvian Outdoor Association "Outdoor Club Latvia" in 2018.
\end{abstract}

Keywords - Nature tourism, practical modelling, treehouses.

\section{INTRODUCTION}

As the population of cities, wealth and the average life expectancy rises, traditional tourism is facing significant change. Travellers around the world and in Latvia are more likely to look for unique recreational and educational opportunities. Providing additional activities as well as unique spatial and sensory solutions have become new drivers for accelerated growth of tourism in Latvia and abroad [1]. Experience-driven nature tourism gets significantly more response from visitors than just providing accommodation. Several of the most popular tourist attractions like ice hotels in Swedish Lapland, "Burning Man Festival" in Black Rock City, Nevada, USA, Conrad Hotel underwater suite in the Maldives, Cliffside Hotel in Cusco, Peru, and Kakslauttanen Igloo Village in Finland near Urho Kekkonen National Park derive their success in combining unique locations and architecture with specially tailored experiences like music performances from instruments that are made of ice in The Igloo Ice Concert Hall in the Arctic region of Luleå, Swedish Lapland, or fire installations in the "Burning Man Festival" [2].

The present study is aimed at exploring the impact of treehouse experiential tourism on local nature tourism activities in regional municipalities in Latvia using temporary practical modelling treehouse installations as a low-risk instrument for establishing the best use cases and approaches for the chosen sites. The research question is how practical modelling workshops can benefit local nature tourism by offering unique activities and findings on opportunities for more permanent treehouse structure design. The study explores a localised view of combining experience-driven nature tourism in Latvia with use of local and recycled materials.

\section{BACKGROUND}

Buildings on trees have been built since antiquity, by primitive tribes hiding in trees from predatory beasts and floods [3]. Over time, more stable dwellings have been favoured and the ability to build shelter in treetops has survived in just a few tribal traditions in Papua New Guinea and Indonesia. Nowadays, thanks to the development of nature-cognitive tourism and economic growth, both in America and in Europe, the tradition of building wooden structures has been unearthed for cognitive, artistic, cultural and hospitality applications [4]. Modern treehouses utilize both the capabilities of new technologies and structural systems comparable to those of ancient tribes. In Latvia, starting from 2014, several residential houses in trees and experimental platforms have been implemented and put into operation [5].

The general methods of treehouse construction using bolt systems have been researched in the United States in books by Pete Nelson [6], several academic papers on structural analysis [4], [7] and further promoted through TV shows like "Treehouse Masters". In Europe, practical modelling activities have taken place in Switzerland, the Netherlands, Italy, France and Germany. One of the most recent studies was conducted by professor Ferdinand Ludwig, scientific coordinator of the Research Group "Baubotanik" at IGMA, which investigates the cultivation of multi-level building facades and load-bearing structures from the willow seedlings and the analysis of structural durability and strength of advanced tree grafting methods [8].

\section{Methodology}

Practical modelling was used as the main research method for testing different types and use cases for roles of a treehouse in boosting nature tourism growth. Qualitative data analysis was used through 30 expert interviews and quantitative data analysis on 210 examples of most popular treehouses organised by structure types, forms of usage, accessibility and available amenities. The experts were selected through the publicly available information on the organizers, promoters and builders of commercially active treehouses and their visitors and owners, including the contacts and experience gained during practical modelling events organized by the author (Fig. 1). Face-to-face and phone expert interviews were conducted, introducing respondents to the topic and structure of the work and then asking for detailed answers to the following questions:

1. what is your current and past involvement with treehouses;

2. what are your expectations regarding public interest in treehouses and nature tourism; 


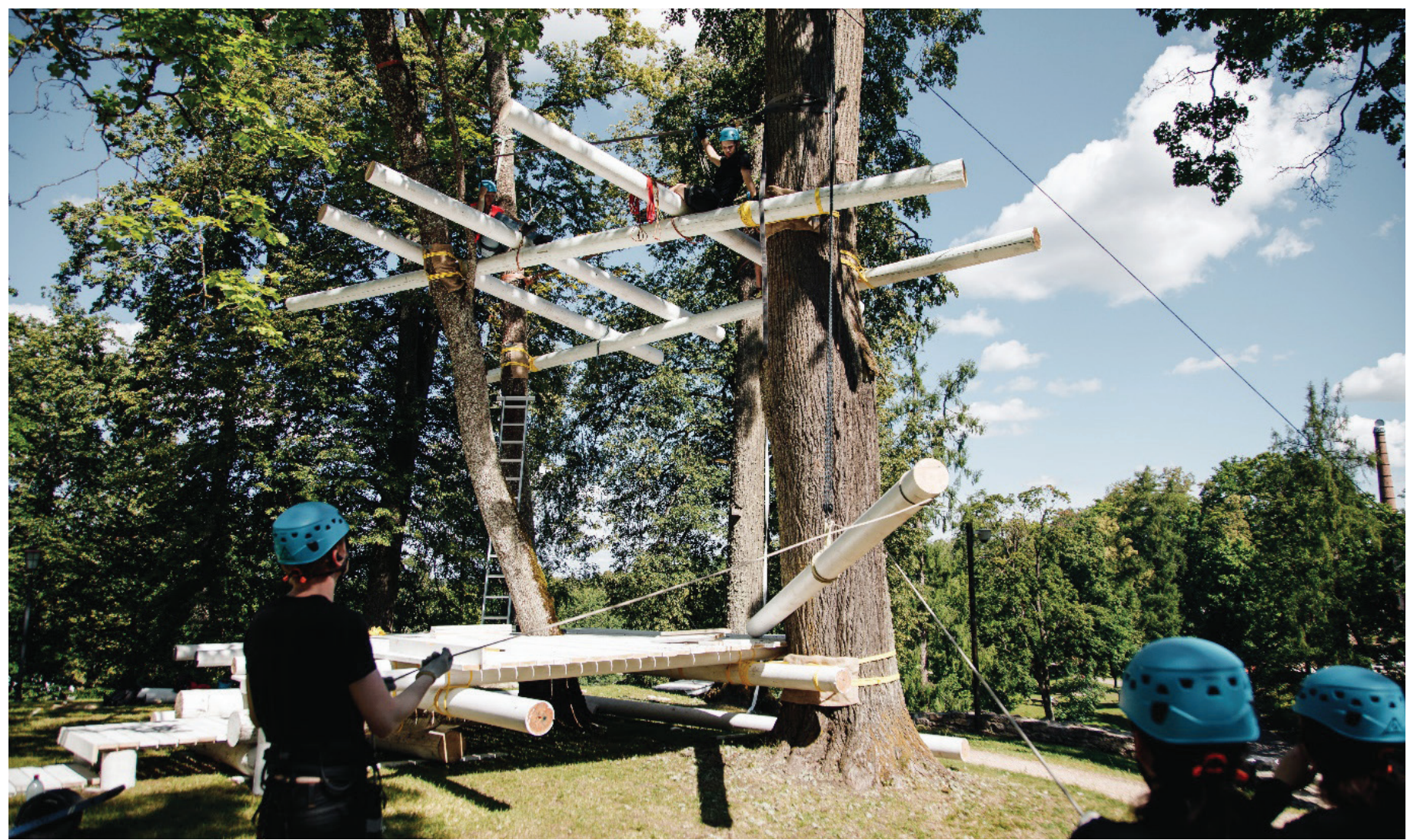

Fig. 1. Treehouse workshop 2018 in Cēsis Castle park. M. Babris on the left [Photo: Andra Marta Babre].

3. what risks and benefits do you see in using treehouses in tourism;

4. do you see treehouses as a seasonal or all-year tourism opportunity;

5. what are your recommendations for promoting nature tourism.

\section{Designing a Treehouse: Comparison of Fasteners and Structural Solutions}

When designing structures in trees, the process of developing an idea, much like in traditional construction, usually begins with measuring and surveying the site. The choice of space for treehouse design is, however, considerably more limited than in traditional construction because of the need to use existing trees and the limited ability to create new support points. During the site inspection and survey it is also important to consider the orientation of the tree and the growth and deformation of the trunk. It is especially crucial to accurately determine the diameter of the trees at a different height, their exact position, angle and rotation in relation to other trees. Particular care should be taken with trees with fragile wood, like willow and aspen where pests and softwood failures are also more likely to be found. Construction is not recommended in birch and other tree species with dense wood, yet poor resistance to trunk damage. In Latvia, it is also possible to build treehouses in oak trees, if the tree canopy and branch width and angle allow it. Special attention should be paid to trees placed adjacent to water bodies. Presence of several fallen trees in the vicinity of a body of water is a sign that similar risk of falling exists for other nearby trees.

In cases where the designed structure is to be based solely on trees, without additional support on the ground, their size, diameter, species and location can have a decisive influence on the geometry of the building. The construction of a public building also requires the arborists' opinion on the health of the trees used. The measurements obtained play a decisive role in the selection of the appropriate anchorage for supporting the timber structures. Nowadays, 3D scanning methods can prove to be a big asset in positioning treehouses, creating a 3D digital tree model from which detailed accurate measurements can subsequently be made, as well as a clearer understanding of the distances between trees and their foliage levels. Particularly important these measurements are when constructing more complex geometry in trees, such as the Healdsburg Treehouse (Redwood, USA) by architect Dustin Fielder, where the geodesic domes of the building are modelled on a 3D model of a tree created by a LiDar laser scanner. The author of the building, D. Fielder, mentions that without such precision it would not be possible to carry out the construction with a corresponding level of detail [9]. The spatial model of the tree canopy is also important when planning the balancing of the treehouse, given the constant movement of trees in the wind and their growth over time it is a subject of change (Fig. 2). 


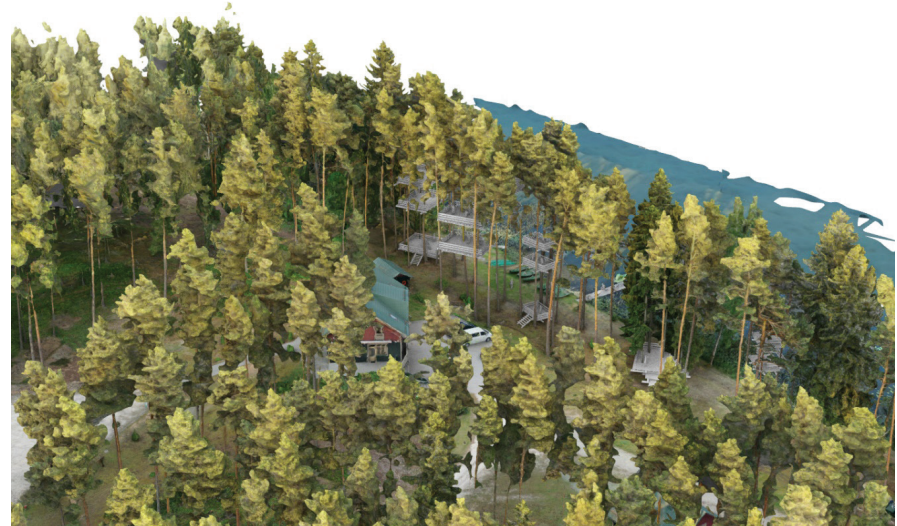

Fig. 2. Positioning of treehouse beams using 3D photogrammetry model in the treehouse project near Spāre guest house [Screen capture: M. Babris].

Age of the trees - pines with a required diameter of $30 \mathrm{~cm}-$ for construction in forests in Latvia is around 60-80 years, so the architect's influence on site selection is significantly limited by choice of the best location and available trees that have been growing there for generations. Accordingly, in designing treehouses, nature has much more direct influence on the orientation, location and overall architectural image of the final project. Most interesting results are achieved when instead of changing the current situation the designer and engineer just look for ways to build constructions into spatial frames already provided by the tree canopy. When planning structures in trees, particular attention should be paid to the analysis of the trees used. When selecting the trees for construction, the tree species and possible health and mechanical damage are important. Attention is also to be paid to the shape of the tree crown and the distribution and transmission of the load on the tree roots. In the climatic conditions of Latvia, founder of website www.majakokos.lv, local treehouse developer, builder and owner Valdis Valainis, and arborist Dainis Penka from "Koku Alianse" Ltd, recommend choosing pine trees that are more durable and usually grow closer together, allowing them to be connected with shorter beams. Pine trees also stand out for their higher wood density, providing a maximum load-bearing

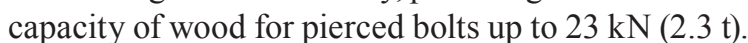

Different treehouse structures are mainly systematized by their application form, construction and fastener types used. The maximum load-bearing capacity, life-span and tectonic shape of the building can be determined by taking into account the specific structure of the treehouse support, their fastening methods and the resulting limitations and capabilities of the treehouse structure. By load transfer types, the structures are divided into three main groups: structures based directly on the tree canopy, structures with partial load transfer on a separate foundation, and solutions with intermediate load transfer frames. There are 5 main corresponding types of fasteners for attaching and securing treehouses.

1. Bolt fasteners - drilled or nailed metal joints in wood:

a) metal pins - anchors (Michael Garnier Limb);

b) nails and bolts.

2. Hanging treehouses.
3. Structures with partial load transfer to artificial supports (columns).

4. Organically supported treehouse structures:

a) arbo-architecture and treehouses for living;

b) spatial grid systems;

c) nest-houses and wicker mesh;

d) tree canopy (branch) supported structures.

5. Ring constrictors:

a) permanent metal hoops;

b) elastic knot systems.

Belt constrictors, metal hoops and bolt fasteners were explored during the practical modelling workshops, however, rope knot system was chosen as the main connector solution for its ability to provide several degrees of freedom in lateral and axial movement that is essential for a stable treehouse structure (Fig. 3).

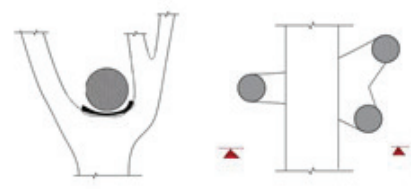

a)

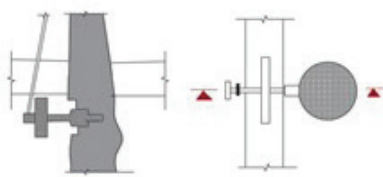

b)

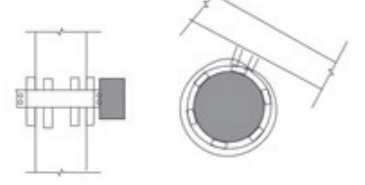

c)

Fig. 3. Shcematic drawing of considered treehouse connector types during practical modelling workshops: a) natural support - nature friendly, very rare for pine trees; b) drilled metal support unit - requires thicker timber and regular maintenance (AKA Michael Garnier limb); c) belt connector - easy installation, but has to be manually adjusted every few years [Figure: M. Babris].

\section{Treehouse Types and Regional Differences}

Treehouses are categorized into three main groups.

1. Solutions created by amateurs and enthusiasts.

2. Constructions developed by companies specializing in the construction of standardised treehouses (Pete Nelson Treehouse, Treehouse Life, Casa Na Avore, Free Spirit Spheres).

3. Treehoses developed by individual architecture office projects (Baumraum, Snohetta, IanD Studio). 


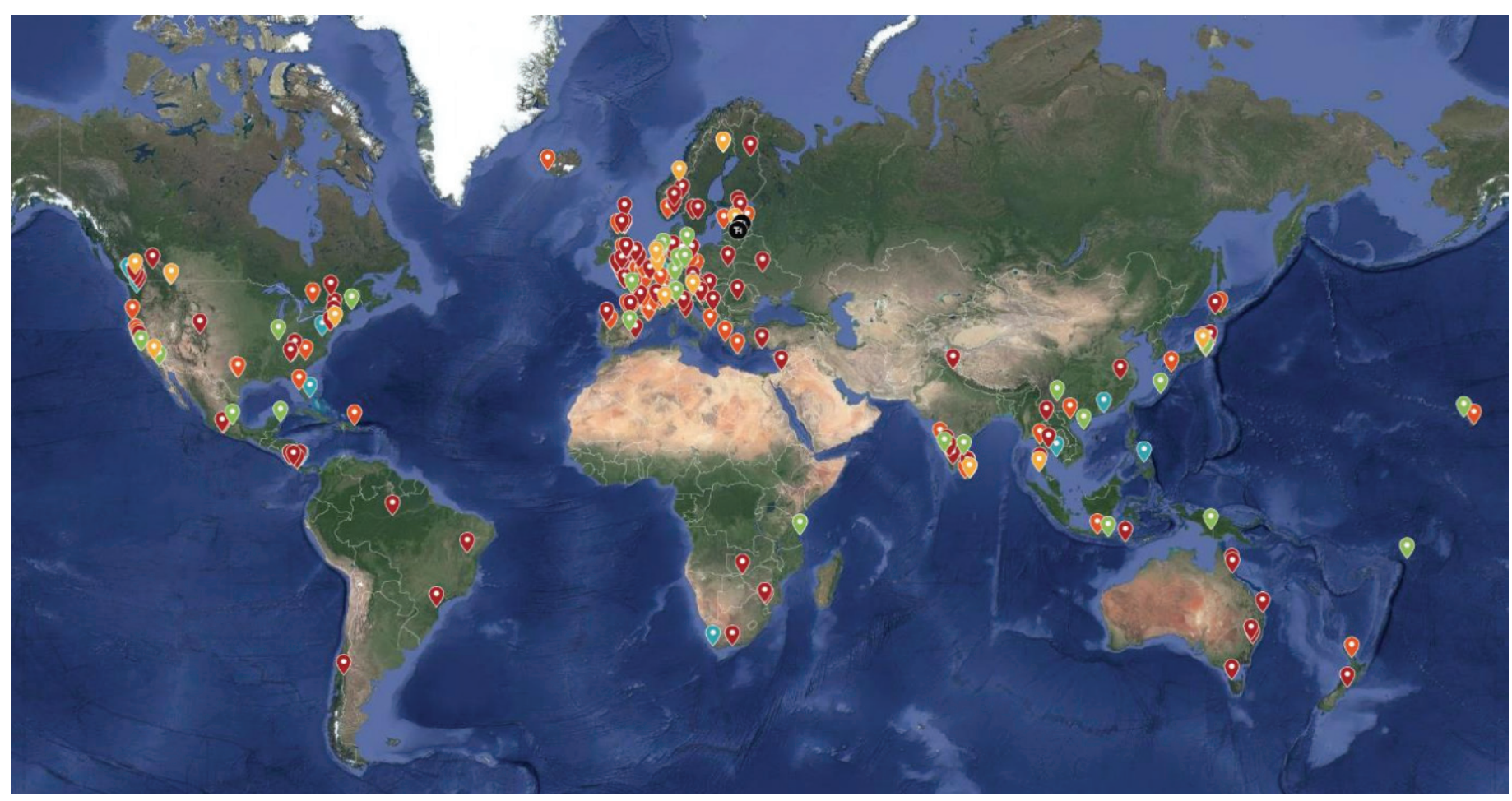

Fig. 4. Treehouses are displayed by type of construction: red-column supports; orange-drilled bolts; green-organic supports; and yellow-ring type constrictors and knots [Marked by M. Babris].

The number of architecture offices specializing in treehouse construction is comparatively small, thus many of the analysed treehouses are built individually without a project or constructed by specialised treehouse and adventure park construction companies. A considerable part of the available educational literature on the realization of structures in trees is also accordingly mainly focused on self-made amateur and enthusiast projects.

After compiling and analysing information on 210 publicly accessible treehouses, it can be seen that such structures are common throughout the world, which can be seen in the map in Fig. 4. The main factors influencing the treehouse structures are the distribution of tree species, differences in climatic factors and regulatory conditions in construction. The largest density of treehouses was witnessed in Central Europe, the United States and the Equatorial climate zone near the South and East China sea and the Sea of Japan. Fewer treehouses are located near deserts, poles and in less economically developed locations. The most common type of structure fasteners were bolt anchors and column support solutions (Fig. 4).

Recreational structures in trees are created for different functions, depending on the location, the client's wishes and the project settings. Analysing of the publicly available examples of treehouse structures for attracting tourists showed that the most common forms of use cases from the compiled 210 examples of publicly available structures in trees are as follows:

1. hotels, accommodation - 130;

2. dwelling houses in trees -37 ;

3. objects of interest, sightseeing platforms, attractions -18 ;

4. tents in treetops, glamping -9 ;
5. restaurants, cafes -7 ;

6. outdoor camping platforms -7 ;

7. office spaces -3 ;

8. outdoor cinema -1 .

During the practical modelling workshops in Latvia, restaurant, café, sightseeing platform, outdoor camping and outdoor cinema functions were tested.

\section{Building a Treehouse: Practical Modelling Workshops in Municipalities in Latvia}

In order to test treehouse construction in local situation 3 different regions in Latvia where chosen (Table I): sightseeing platform near Kegums on a private-owned land, constructed in 2016, acoustic concert platforms in a public area in Strenči municipality near the Gauja River and Natura 2000 zone, constructed in 2017, and discussion platforms in Conversation festival "Lampa" in Cēsis town park, constructed in summer 2018.

TABLE I.

Impact of Treehouse Modelling Workshop on Local TOURISM Development in Latvian Municipalities [M.Babris].

\begin{tabular}{|l|l|l|l|}
\hline Year & Location & $\begin{array}{l}\text { Number of } \\
\text { visits }\end{array}$ & Main functions and activities \\
\hline 2016 & Kegums & 120 & Sightseeing platform \\
\hline 2017 & Strenči & 3200 & $\begin{array}{l}\text { Café, nature concert, adventure } \\
\text { platforms }\end{array}$ \\
\hline 2018 & Cēsis park & 16000 & $\begin{array}{l}\text { Discussion and concert platforms for } \\
\text { the Conversation festival LAMPA }\end{array}$ \\
\hline
\end{tabular}




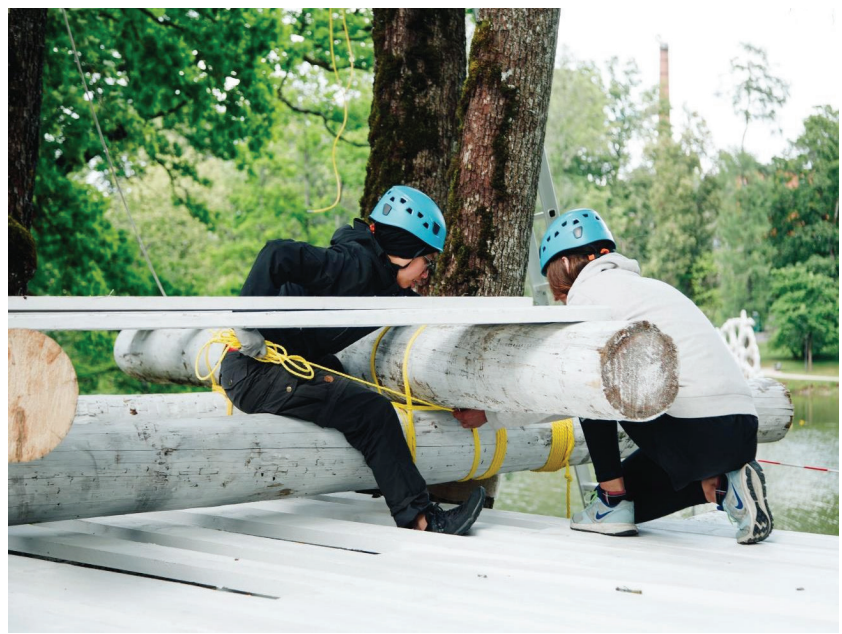

Fig. 5. Nature friendly knot system, utilised in Latvian treehouse workshops is elastic, allows movement and protects tree trunks [Photo: Matijs Babris].

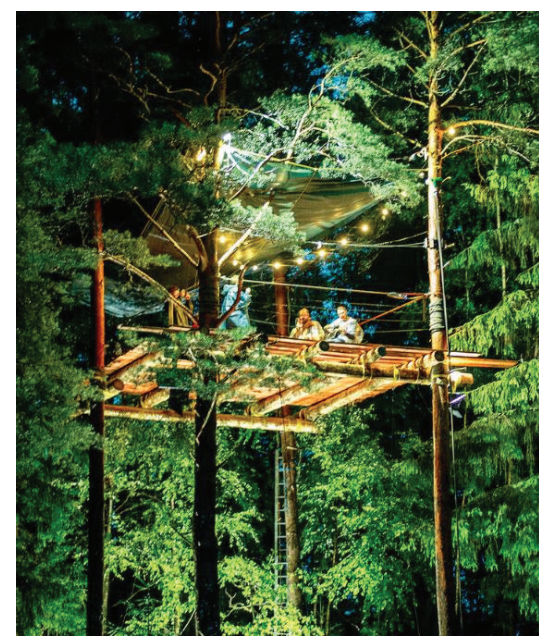

Fig. 6. Finished concert platform for Kegums treehouse workshop in summe 2016 [Photo: Matijs Babris].

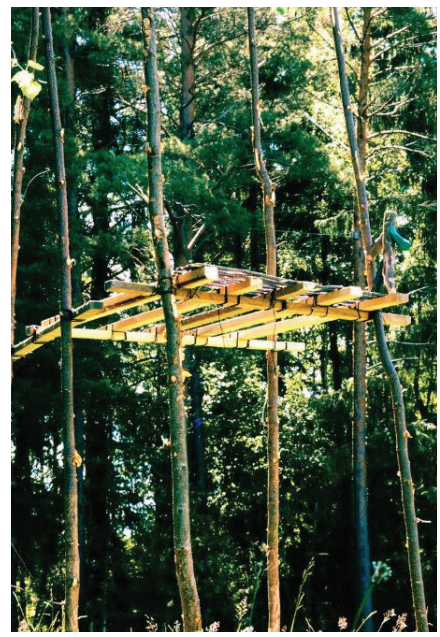

Fig. 7. The first treehouse prototype scale model on location, built using branches and sticks [Photo: Matijs Babris].
When looking for the best constructive solution for building permanent treehouses, several authors and builders in conducted interviews pointed out the value of practical modelling on site (Figs. 6 and 7) in trying to find the best aesthetic and constructive solution. Real-time modelling of treehouse constructions on-site with lightweight temporary fasteners can be very useful. The variable geometry of trees is relatively difficult to translate into a computer environment, thus being present on the site is essential for the architect and offers great added value to the project.

The knotting system used was adopted from the Netherlands as tested in practical modelling classes and was well compatible with the workshop format, as it had neglible effect on the used tree trunk bark (Fig. 5). During the workshop in Strenči Municipality, Janis Pētersons, Chairman of the Strenči Municipal Council, expressed his support for the possibility of introducing workshops at relatively lower costs and in a shorter period of time to see if it would be feasible to realize a larger facility that would attract more serious investment. Arborist Edgars Neilands (Table II) recalled that the arborist profession arose only a couple of decades ago and that public awareness of trees and treehouses can also serve as public education or advertising tool on trees, nature and human interaction. Most workshop participants and treehouse visitors agreed that they would like to experience such activity again and that, alongside the educational function, the opportunity to be closer to nature and practice hands-on teamwork is particularly attractive. The Dutch organization "Buiten Door" and the Latvian Outdoor Activities organisation "Adventure Spirit" have been using treehouse workshops for several years, not as architectural training but as a team-building therapy for more efficient work and a healthier lifestyle. The first architects' workshop near Kegums was organised in close collaboration with the "Adventure Spirit", and a treehouse platform was constructed during a week-long summer camp. The workshop had 24 participants and the nature concert was attended by approximately 120 visitors (Fig. 6).
TABLE II

Interviewed Expert Groups [M.Babris]

\begin{tabular}{|c|c|}
\hline $\begin{array}{l}\text { 1. Arborists, } \\
\text { tree experts }\end{array}$ & $\begin{array}{l}\text { 1.1. Dainis Penka, Koku Aliance Ltd. } \\
\text { 1.2. Edgars Neilands, Labie Koki Ltd. } \\
\text { 1.3. Laila Šica, Head of Environmental Planning } \\
\text { Department, of Latvia's State Forests JSC }\end{array}$ \\
\hline $\begin{array}{l}\text { 2. Construction } \\
\text { boards and } \\
\text { regulatory } \\
\text { authorities }\end{array}$ & $\begin{array}{l}\text { 2.1. Jānis Ziemelis, director of Gulbene Construction } \\
\text { Board } \\
\text { 2.2. Māris Pandalons, director of Valka Construction } \\
\text { Board } \\
\text { 2.3. Gunita Hjortenberg, director of Cēsis Construction } \\
\text { Board }\end{array}$ \\
\hline $\begin{array}{l}\text { 3. Architects } \\
\text { and city } \\
\text { planners }\end{array}$ & $\begin{array}{l}\text { 3.1. Ervīns Gorelovs, student, Zhejiang University, China } \\
\text { 3.2. Dr. Arch. Sandra Treija, Riga Technical University } \\
\text { 3.3. Sergejs N̦ikiforovs, architect, Nams Ltd. } \\
\text { 3.4. Dr. Arch. Ugis Bratuškins, Riga Technical University } \\
\text { 3.5. Uǵis Šēnbergs, architect }\end{array}$ \\
\hline $\begin{array}{l}\text { 4. Treehouse } \\
\text { builders }\end{array}$ & $\begin{array}{l}\text { 4.1. Valdis Valainis, construction engineer, majakokos.lv } \\
\text { 4.2. Viesturs Lūsis, NGO Adventure Spirit } \\
\text { 4.3. Floris Muller, board member, BuitenDoor } \\
\text { 4.4. Guntis Avotiņš, founder of Tīklu parki Ltd. } \\
\text { 4.5. Florian Klepper, manager of BuitenDoor }\end{array}$ \\
\hline $\begin{array}{l}5 . \\
\text { Municipalities }\end{array}$ & $\begin{array}{l}\text { 5.1. Jānis Pētersons, Head of Strenči Municipality } \\
\text { 5.2. Iveta Kovtuņenko, Gulbene Tourism and Cultural } \\
\text { Heritage Centre } \\
\text { 5.3. Iveta Ence, Head of Planning and Development } \\
\text { Department of Strenči Municipality }\end{array}$ \\
\hline $\begin{array}{l}6 . \text { Project } \\
\text { managers, } \\
\text { clients and } \\
\text { visitors }\end{array}$ & $\begin{array}{l}\text { 6.1. Guntars Anspoks, enterpreneur, seasonal Treehouse } \\
\text { hotel in Priedaine } \\
\text { 6.2. Lelde Prūse, producer of Conversation Festival } \\
\text { Lampa } \\
\text { 6.3. Rūdis Rubenis, workshop participant, treehouse } \\
\text { place in Strenči } \\
\text { 6.4. Normunds Namnieks, recreation and hunting project } \\
\text { manager, Latvia's State Forests } \\
\text { 6.5. Liene Briede, project manager, RTU Idea LAB } \\
\text { 6.6. Gunita Kuḷkovska, enterpreneur } \\
\text { 6.7. Paulis Bārzdiňš, musician performing in a treehouse } \\
\text { concert }\end{array}$ \\
\hline
\end{tabular}




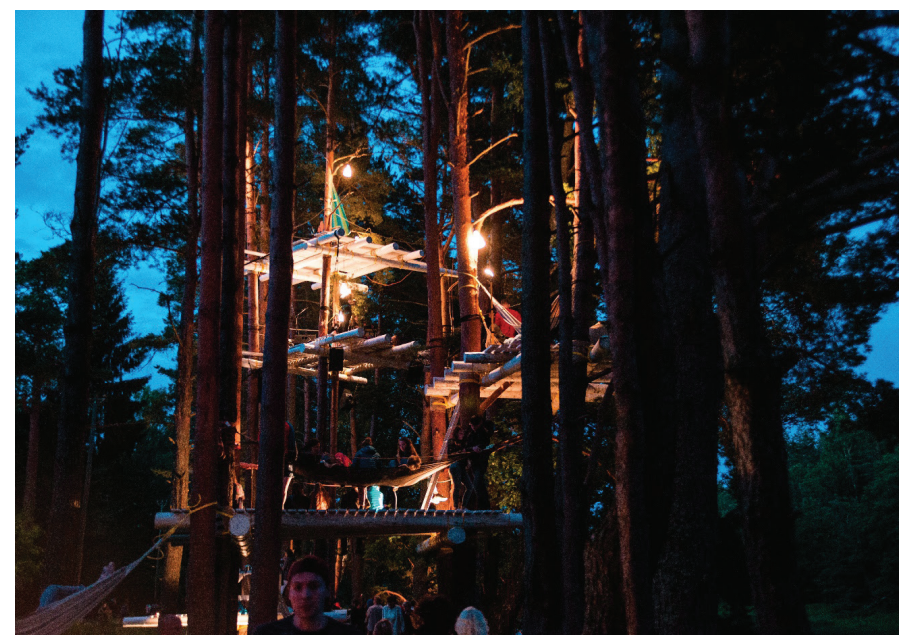

Fig. 8. Treehouse Festival in Strenči city in summer 2017 [Photo: SIA AM Foto].

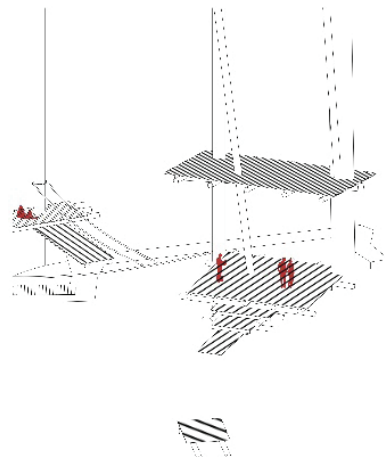

Fig. 10. Axonometry of the main youth stage of the treehouse Cēsis Castle park

Construction materials and learnings from the first sightseeing platform treehousein Kegums (Fig. 6) were used in next years during Adventure Festival in Strenči Municipality constructing a combination of several treehouse platforms near the Gauja river. A resulting platform for testing purposes was left as an installation for the whole year also through winter; it was widely attended at Christmas concert that took place during the holiday season at $-2{ }^{\circ} \mathrm{C}$ air temperature. Collaboration with the local municipality provided several further cultural, sports and social activities during the year for the treehouse platforms which were included in regional tourist guides, mentioned in TV [10] and even received regular tourist flow by buses from as far as Germany. By estimated calculations, during the year the treehouse platform was visited by around 3200, which was 3 times more than 1018 registered local residents in the town of Strenči. Several of the local residents and youngsters also participated in the open lectures on tree health and attended craftmanship lessons. The workshop took place for 2 weeks, and in total 7 treehouse platforms were built with a pop-up café, game room, watchtower, hammock lounge, climbable net installation and concert platforms with piano and electrical instruments (Fig. 8).

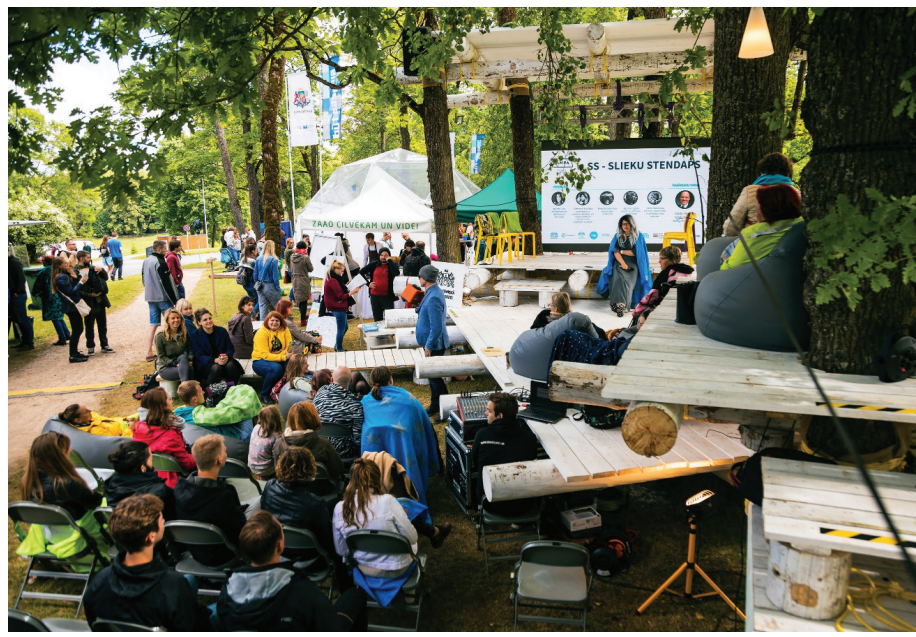

Fig. 9. Discussion platforms in LAMPA Conversation Festival in summer 2018 [Photo: Andra Marta Babre].

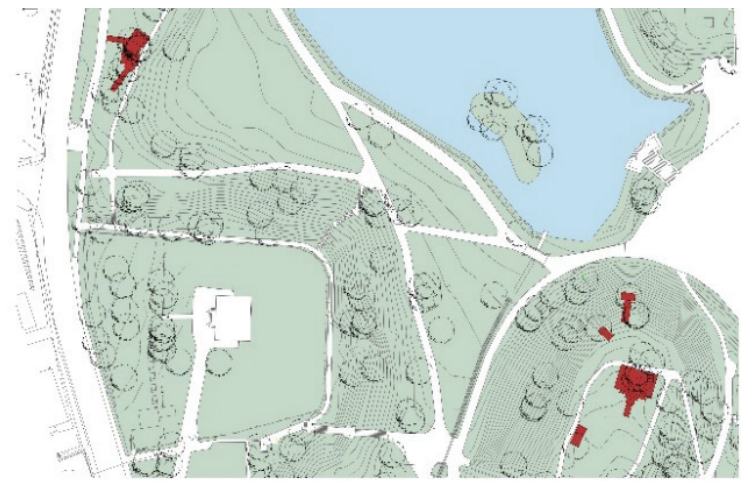

Fig. 11. Arrangement of treehouse platforms in Cēsis Castle park. Summer 2018.

The last Treehouse workshop was organised in Cēsis Castle Park during the local Conversation Festival Lampa in 2018 (Fig. 9). The workshop took place for 2 weeks and in total 12 platforms were built overlooking the castle park, providing seating for attendees and featuring 2 stages for discussions, presentations and other cultural activities regarding climate change and youth policy in Latvia (Figs. 10 and 11). Both clients, Lelde Pruse, festival organiser, and Liene Briede, event coordinator, referred to the gained experience very positively noting the significant increase of visitors to areas where treehouses were located. L. Pruse particularly appreciated the possibility of using the areas that due to the large number of trees had not previously been suitable for tent placement or other activities. One of the goals for the inclusion of treehouses in the event program was the challenge of attracting attendees to the Cesis Castle Park area on top of Riekstukalns hill, which due to the elevated location was usually less visited than the other park territories. Strategically situated festival platforms on treehouses for young people generated a significant increase in visitor interest bringing to life a previously problematic area, with a total attendance of 16000 people on the weekend, and a total of around 47000 spectators online, which was a record number for this event [11]. 


\section{Conclusions}

Experience and educational tourism represent a significant opportunity for the future growth of nature tourism. By diversifying the experience gained, regional revitalization, as well as local entrepreneurship, can be promoted.

Treehouses allow creating a unique and valuable space for tourism in nature parks and other protected areas. They are easy to supplement and use both seasonally and throughout the year, highlighting local natural landscapes with minimal environmental impact.

Seasonal and temporary treehouse construction is usually faster and more budget-friendly, allowing testing the viability of the site before making a larger investment. Treehouses can also be realized in parks and public areas, providing a unique opportunity for concerts, events and seminars during the summer season.

Nature-friendly knot system construction used in practical modelling workshops, carried out during research, best fit short term public activities like festivals, concerts and pop-up events.

Results from practical modelling workshops demonstrate a high level of user satisfaction and the ability to use seasonal construction sites in nature parks where traditional construction methods tend to be more challenging to implement.

When choosing a place to build treehouses, it is important to look critically at the available trees and their species. Arborists and treehouse experts recommend choosing hardwood trees. The most suitable species in Latvia are oak and pine trees.

For the broader development of treehouses, it is important to improve legislation by establishing a standardized approach. The European Rope Parks Association is a good example of such a directive and its successful implementation in standardizing the construction and safety of rope parks in Europe.

\section{REFERENCES}

1. Jensen, Ø., Prebensen, N. Innovation and Value Creation in Experi ence-based Tourism. Stavanger, Scandinavian Journal of Hospitality and Tourism, 2015, Vol. 15, Issue 1, pp. 1-8.

https://doi.org/10.1080/15022250.2015.1066093

2. Hjalager, A.-M. Repairing innovation defectiveness in tourism. Tourism Management, Vol. 23, Issue 5, 2002, pp. 465-474. https://doi.org/10.1016/S0261-5177(02)00013-4

3. Head-Hunters Drove Papuan Tribe Into Tree-Houses. Netherlands Organisation For Scientific Research, 1998 [online]. Science Daily [cited 10.09.2019]. https://www.sciencedaily.com/releases/1998/03/980309043026.htm

4. Henderson, P., Mornement, A. Treehouses. London: Frances Lincoln Publishers, 2008. $175 \mathrm{p}$.

5. Atpūtas ēka - Brīvdienu māja, Gada labākā būve Latvijā [online]. Riga Latvijas Būvinženieru savienība, 2017 [cited 10.10.2018]. http://www. buvinzenierusavieniba.lv/skate-\%E2\%80\%9Egada-labaka-buve-latvija-2017\%E2\%80\%9D-tiek-nosauktas-gada-labakas-buves-latvija-un-godinati-to-buvnieki

6. Nelson, P. TreeHouses of the World. New York : Harry N. Abrams inc. 2004. $224 \mathrm{p}$

7. TreeTopBuilders inc. Professional Cnstruction of Tree Houses [online] TreeTopbuilders.net 2018 [cited 22.04.2018]. https://www.treetopbuilders. net/fasteners/

8. Ludwig, F. Botanical basics of Baubotanik and their application to design principle. Stuttgart: OPUS - Publication Server of the University of Stuttgart, 2012. http://dx.doi.org/10.18419/opus-86

9. Lewis, J. F. The Anatomy of Treehouses: Stylish Hideaways and Retreats. Kaysville, Utah, US: Gibbs Smith publisher, 2018. 224 p.

10. Mājas kokos top pilnā sparā - LNT Brokastis. Latvijas Nacionālā Televīzija 2017 [online, cited 10.09.2019]. http://tv3play.skaties.lv/majas-kokos-toppilna-spara-lnt-brokastis-10249735
11. Lampa 2018 pulcējusi 16000 apmeklētāju [online]. Sarunu festivāls lampa. festivalslampa.lv 03.08.2018 [cited 10.09.2019]. https://www.festivalslampa.lv/lv/jaunumi/lampa-2018-pulcejusi-16-000-apmekletaju.

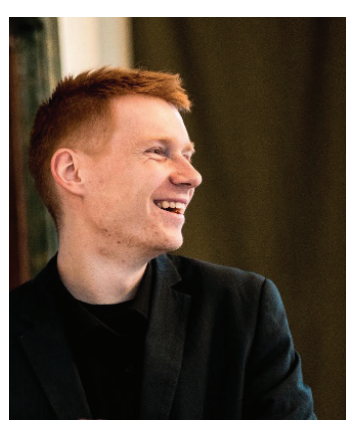

Matijs Babris (b. Riga 1993) obtained his degrees B. arch. (2016) and M. arch. (2018) from Riga Technical University. His current research is on management and application of creative process in Architecture. He has organised and participated in several practical and theoretical architecture student workshops with local municipalities in Latvia and abroad on issues regarding local tourism development and nature tourism.

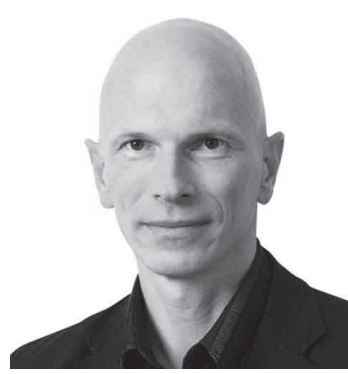

Uğis Bratuškins, Dr. arch., is currently an architect (b. 1961), Professor of Riga Technical University, the Dean of the Faculty of Architecture. He received the degree of Master of Architecture in 1994 and the degree of Doctor of Architecture in 2006. Since 1984, he has been a practicing architect with the design bureau Komunālprojekts Ltd. and Sestais Stils Ltd. $\mathrm{He}$ is a member of the Latvian Association of Architects. He is the author of more than 60 publications. He is a member of Editorial Boards of such journals as Architecture and Urban Planning (Riga, Latvia), Journal of Architecture and Urbanism (Vilnius, Lithuania), Landscape Architecture and Art (Jelgava, Latvia), and The Journal of Sustainable Architecture and Civil Engineering (Kaunas, Lithuania). He is an expert of Fondazione Romualdo Del Bianco (Florence, Italy) and Slovenian Research Agency (Ljubljana, Slovenia).

\section{Contact Data}

\section{Matijs Babris}

Faculty of Architecture, Riga Technical University

Address: 6 Kīpsalas St., Riga, LV-1048

E-mail: matijs.babris@gmail.com

\section{Uǵis Bratuškins}

Faculty of Architecture, Riga Technical University

Address: 6 Ķīpsalas St., Riga, LV-1048

E-mail: ugis.bratuskins@rtu.lv 